Jejaring Administrasi Publik, Vol. 12, No. 1, 2020, hal 18-34

\title{
Analisis Inovasi Layanan Perizinan Pada Dinas Penanaman Modal dan Pelayanan Terpadu Satu Pintu (DPMPTSP) DKI Jakarta: Service Poin Pelayanan Perizinan Pasar Rebo
}

\author{
Analysis of Licensing Service Innovation at the DKI Jakarta One Stop \\ Integrated Service and Investment Service: Service Points for Pasar Rebo \\ Licensing Services
}

\author{
Bambang Agus Diana ${ }^{1}$, Refita Aulina ${ }^{2}$ \\ ${ }^{1,2}$ Fakultas Ilmu Sosial dan Ilmu Politik, Universitas Terbuka \\ E-mail: bambangad@ecampus.ut.ac.id
}

\begin{abstract}
To realize Excellent Service to the Community, the DKI Jakarta Capital Investment and One Stop Integrated Service has carried out various innovations which Implementation through the One Stop Service Policy (OSSP) is one of the policies of the DKI Jakarta Provincial government to provide excellent service to the community, especially in licensing and nonlicensing services with the right, fast, easy, cheap and transparent service. Innovation always starts with creativity, that is, starting with thinking about things that never existed. This process of making new things happen is called innovation (levitt). Meanwhile, Gareth Jones innovation is a process where organizations use their expertise and resources to develop production and operating systems so that they can better respond to consumer demands. Evert M. Rogers. The research method uses qualitative research methods to read the phenomena that occur in social conditions, especially the impact of DPMPTSP innovation on society. . One of the roles of the One Stop Services and Investment Bureau of DKI Jakarta Province is to increase promotion and investment opportunities through simplifying procedures for proper, fast, simple and inexpensive licensing and non-licensing services.
\end{abstract}

Keywords: Innovation, Integrated Services, Technology

\begin{abstract}
Abstrak
Untuk mewujudkan Pelayanan Prima kepada Masyarakat maka Dinas Penanaman Modal dan Pelayanan Terpadu Satu Pintu ( DPMPTSP) DKI Jakarta melakukan berbagai inovasi yang Penyelenggaraan melalui One Stop Service Policy (OSSP) ini merupakan salah satu kebijakan pemerintah Provinsi DKI Jakarta untuk memberikan pelayanan prima kepada masyarakat terutama pada pelayanan perizinan dan non-perizinan dengan pelayanan yang tepat, cepat, mudah, murah dan tranparansi. Inovasi selalu dimulai dengan kreativitas yaitu memulai dengan memikirkan hal-hal yang belum pernah ada. Proses mewujudkan hal yang baru ini disebut dengan inovasi (levitt). Sementara Gareth Jones inovasi sebagai suato proses dimana organisasi menggunakan keahlian dan sumberdaya untuk mengembangkan sistem produksi dan operasi sehingga mereka dapat memberi tanggapan atas tuntutan konsumen
\end{abstract}


secara lebih baik. Evert M. Rogers. Metode penelitian menggunakan metode penelitian kualitatif untuk membaca fenomena yang terjadi dalam kondisi sosial khususnya dampak inovasi DPMPTSP pada masyarakat. . Salah satu peran Biro Pelayanan dan Penanaman Modal Terpadu Satu Pintu Provinsi DKI Jakarta adalah meningkatkan peluang promosi dan investasi melalui penyederhanaan prosedur pelayanan perizinan dan nonperizinan yang tepat, cepat, sederhana dan murah.

Kata Kunci: Inovasi, Pelayanan terpadu, Teknologi

\section{Pendahuluan}

Jakarta adalah ibu kota negara Indonesia, yang telah mengalami perkembangan dan kemajuan yang pesat di berbagai bidang. Kota Jakarta berkembang pesat di berbagai faktor seperti pusat perkantoran, perdagangan, pemerintahan, perdagangan, dan permukiman, sehingga banyak orang cenderung mencari nafkah di Jakarta. Situasi seperti inilah yang menyebabkan Jakarta diserbu oleh para pendatang, dan jumlah ini terus meningkat setiap tahun, mengakibatkan tingkat penduduk yang semakin tinggi.

Banyak imigran atau pendatang biasanya tinggal dan hidup di Jakarta untuk mencari peruntungan, dan hanya sedikit yang tinggal dan keluar masuk Jakarta yaitu ketika mereka bekerja seperti masyarakat yang bekerja dijakarta namun tempat tinggal mereka didaerah perbatasan Ibukota dan kota sekitarnya diluar Jabodetabek yang bisa ditempuh dengan hitungan jam saja. Dengan demikian, wilayah terpadat di Indonesia adalah DKI Jakarta dengan jumlah penduduk 10,57 juta jiwa yang tersebar di 5 kota administratif dan 1 kabupaten. Karena itu, periode Gubernur DKI Jakarta (2012-2014). Joko Widodo (Gubernur DKI saat itu) memberikan gagasan tentang layanan pemerintahan yang dapat dibuka untuk umum dalam bentuk layanan cepat dan berlisensi langsung dan tidak berlisensi.

Pada Januari 2015, Gubernur DKI Jakarta dan penggantinya Basuki Tjahaja Purnama menerapkan Badan Layanan Terpadu Satu Pintu (BPTSP) yang benar-benar melaksanakan rencana tersebut. Pada Januari 2017, badan tersebut berganti nama menjadi DKI Jakarta Pelayanan Penanaman Modal dan Pelayanan Terpadu Satu Pintu (DPM PTSP), dengan harapan bisa lebih mudah mendapatkan izin penanaman modal di Provinsi DKI Jakarta, yakni untuk mendapatkan perizinan, non perizinan secara cepat, murah dan cepat. Pelayanan publik secara sederhana, transparan, pasti, terjangkau dan bertanggung jawab, serta meningkatkan hak masyarakat untuk mengakses layanan publik, dapat dilakukan di satu tempat melalui sistem online, dan tatap muka di 316 titik layanan Unit Pengelola 


\section{Diana dan Aulina: "Analisis Inovasi Layanan Perizinan Pada Dinas Penanaman Modal dan Pelayanan Terpadu Satu Pintu (DPMPTSP) DKI Jakarta"}

PMPTSP Tersebar di wilayah Kota/Kabupaten, Kecamatan, Kelurahan dan Mal Pelayanan Publik provinsi DKI Jakarta. Penulis berkomitmen untuk mengetahui dan mencari tahu bagaimana pelayanan terpadu satu Pintu DKI Jakarta terhadap inovasi pelayanan perizinan dan nonperizinan DKI Jakarta dalam meningkatkan kepuasan masyarakat terhadap izin pengelolaan DKI Jakarta. Salah satu yang utama dalam tujuan penulisan ini yaitu ingin mengetahui inovasi perizinan di DPMPTSP DKI Jakarta, dan sejauh mana kepuasan msayarakat dengan penanganan perizinan Terpadu satu Pintu tersebut. Berdasarkan tujuan dirumuskan permasalahan penelitian: (a) Inovasi apa saja yang dilakukan DPMPTSP DKI Jakarta untuk meningkatkan good governance?;

(b) Apa dampak inovasi terhadap kepuasan pegawai DKI dalam proses perizinan?

\section{Teori Pelayanan Publik berbasis Good Governance}

Pelayanan publik sangat identik dalam kehidupan manusia seharian mulai dari lahir seseorang harus memiliki akta kelahiran, surat identitas, pelayanan kesehatan keamanan dan ketertiban, hak-hak untuk hidup secara adil dan hak untuk pelayanan dasar seperti penyediaan bahan bakar, air, listrik dan surat menyurat yang menjadi kebutuhan dasar (Said, 2012: 2). Pelayanan publik merupakan salah satu paremeter penilaian pada tingkat kemajuan reformasi birokrasi dan penyelenggaraan pemerintahan dengan tata kelola yang baik (good governance). Dalam hal ini pemerintah memiliki peran dan fungsi dalam pengaturan pelayanan terhadap masyarakat. Salah satunya peranan yang dijalankan oleh pemerintah adalah pelayanan publik baik yang berkenaan dengan birokrasi maupun administrasi seperti fungsi alokasi, distribusi dan stabilisasi salah satunya pelayanan yang baik harus diwujudkan dalam pemerintah yang secara langsung dapat di rasakan di masyarakat.

\section{Definisi Pelayanan Publik (Public Service)}

Pengertian pelayanan publik memiliki dimensi yang beragam, tergantung dari sudut pandang dalam menggunakan istilah tersebut. Pelayanan menurut Kamus Besar Bahasa Indonesia (KBBI) adalah sebagai suatu usaha untuk membantu menyiapkan atau mengurus apa yang diperlukan orang lain. Menurut Jemes dan Mona (2004), mendefinisikan konsep pelayanan publik dengan terlebih dahulu menjelaskan tentang pelayanan, pelayanan menurutnya bersifat tidak nyata (intangible) dan tidak tahan lama. Ratminto \& Winarsih (2006) mengartikan pelayanan sebagai "suatu aktivitas atau serangkaian aktivitas yang bersifat tidak kasat mata (tidak dapat diraba) yang terjadi sebagai akibat adanya interaksi antara konsumen dengan karyawan atau pegawai. Menurut Sinambela dan Lijan (2011:5) 
"pelayanan publik diartikan sebagai pemberian layanan (melayani) keperluan orang atau masyarakat yang mempunyai kepentingan pada organisasi itu sesuai dengan aturan pokok dan tatacara yang telah ditetapkan".

Menurut pandangan Albert dan Zamke dalam Krisilvana (2016: 7) Pelayanan pada setiap sektor di pemerintahan bukan hanya memberikan pelayanan semata melainkan memberikan pelayanan yang berkualitas dan pelayanan prima. Segala bentuk pelayanan publik yang apabila dilaksanakan dengan pelayanan berkualitas dan prima, tentu akan dapat mewujudkan pelayanan publik berbasis good governance.

\section{Definisi Inovasi}

Inovasi selalu dimulai dengan kreativitas yaitu memulai dengan memikirkan hal-hal yang belum pernnah ada. Proses mewujudkan hal yang baru ini disebut dengan inovasi (levitt). Sementara Gareth Jones inovasi sebagai suatu proses dimana organisasi menggunakan keahlian dan sumberdaya untuk mengembangkan sistem produksi dan operasi sehingga mereka dapat memberi tanggapan atas tuntutan konsumen secara lebih baik. Evert M. Rogers (Suwarno, 2008:9). Pengertian Inovasi adalah suatu ide, gagasan, praktek atau objek / benda yang disadari dan diterima sebagai suatu hal baru oleh seseorang atau kelompok untuk diadopsi.

\section{Definisi One Stop Service}

Model pelayanan publik yang mengintegrasikan berbagai jenis pelayanan pemerintah di satu lokasi memiliki berbagai istilah seperti one stop government, integrated service delivery, seamless government, joined up governrrient, single access point, one-stop shop, one-stop service (Trochidis,2008: 10-11; Kubicek dan Hagen, 2001:7-8). Menurut Trochidis (2008: 10) istilah-istilah tersebut merupakan salah satu praktek yang dominan dilakukan dewasa ini khususnya di negara maju yang mengintegrasikan pelayanan publik dari berbagai institusi pemerintah berdasarkan sudut kepentingan stakeholder. Dengan model pelayanan seperti itu pelayanan kepada masyarakat akan lebih nyaman, mudah diakses, dan bersifat personal.

\section{Model One Stop Service}

Selanjutnya menurut Bent dalam (Kubicek dan Hagen: 2001:8-9) ada tiga jenis model onestop service atau one-stop government berdasarkan tujuannya dapat dibedakan menjadi model-model sebagai berikut: 


\section{Diana dan Aulina: "Analisis Inovasi Layanan Perizinan Pada Dinas Penanaman Modal dan Pelayanan Terpadu Satu Pintu (DPMPTSP) DKI Jakarta"}

- Model First-Stop, merupakan model pelayanan ini berisi pelayanan informasi yang memandu masyarakat untuk mengetahui jenis-jenis pelayanan publik yang dibutuhkannya.

- Model Convenience Store, merupakan model pelayanan ini berisi pelayanan informasi yang memandu masyarakat untuk mengetahui jenis-jenis pelayanan publik yang dibutuhkannya. Berbagai jenis transaksi pelayanan dilokasikan di satu kantor atau mungkin di satu situs internet.

- Model True One-Stop, merupakan model pelayanan ini mengintegrasikan berbagai jenis pelayanan dan melibatkan berbagai kewenangan. Model pelayanan ini digunakan untuk jenis-jenis pelayanan yang cukup kompleks.

\section{Definisi Penanaman Modal (Investment)}

Pada umumnya investasi dilakukan dalam rangka meningkatkan perekonomian, pembangunan, dan lapangan kerja baik di tingkat daerah maupun nasional. Investasi adalah the action or process of investing money for profit (Oxford Dictionary) yaitu segala bentuk tindakan atau proses menanamkan uang untuk memperoleh keuntungan. Sedangkan menurut Jones (1943: 18) dalam bukunya Investment, Analysis, and Management menulis "An investment is the commitment of funds to one or more assets that will be held over some future period". Dalam artian bahwa suatu investasi dapat didefenisikan sebagai komitmen dana pada suatu atau beberapa asset yang akan dipegang selama beberapa waktu mendatang. Kemudian menurut Sukirno (2008: 121) menjelaskan bahwa "penanaman modal adalah pengeluaran atau pembelanjaan penanam-penanam modal atau perusahaan untuk membeli barang modal dan perlengkapan-perlengkapan produksi untuk membeli barang modal dan perlengkapan produksi untuk menambah kemampuan memproduksi barang barang dan jasa jasa yang tersedia dalam perekonomian”. Dengan demikian dapat disimpulkan bahwa penanaman modal merupakan pengorbanan kekayaan untuk memperoleh keuntungan dimasa mendatang dengan resiko tertentu.

\section{Metode Penelitian}

Metode penelitian menggunakan metode penelitian kualitatif untuk membaca fenomena yang terjadi dalam kondisi sosial khususnya dampak inovasi DPMPTSP pada masyarakat. Pengumpulan data penelitian dilakukan pada salah satu service poin pelayanan perizinan yaitu Dinas Penanaman Modal dan Pelayanan Terpadu Satu Pintu (DPMPTSP) Kecamatan Pasar Rebo di Jl. Raya Bogor KM. 27 Pekayon Pasar Rebo Kota Administrasi 
Jejaring Administrasi Publik, Vol. 12, No. 1, 2020, hal 18-34

Jakarta Timur. Selanjutnya untuk sumber data diperoleh melalui pernyataan tertulis dengan menggunakan lisan dan metode wawancara dan menggunakan studi kepustakaan yang biasa digunakan pada penelitian kualitatif. Peneliti terlibat langsung atau riset partisipatori dengan menggunakan teknik interview, observasi, dan dokumentasi."Kegiatan interview yang digunakan adalah interview terbuka, tertruktur, atau tidak terstruktur dan tertutup tertruktur atau tidak terstruktur. Analisis data menggunakan menggunakan analisis data kualitatif model interaktif.

\section{Hasil dan Pembahasan}

Gambaran umum penanaman modal jakarta dan institusi pelayanan terpadu satu pintu sejak tahun 2014, DKI Jakarta menerapkan kebijakan pelayanan satu pintu. Nantinya, Peraturan Gubernur menegaskan bahwa kebijakan tersebut akan menjadi lembaga investasi satu pintu dan pelayanan terintegrasi pada tahun 2017. Salah satu peran Biro Pelayanan dan Penanaman Modal Terpadu Satu Pintu Provinsi DKI Jakarta adalah meningkatkan peluang promosi dan investasi melalui penyederhanaan prosedur pelayanan perizinan dan nonperizinan yang tepat, cepat, sederhana dan murah. Sesuai Peraturan Gubernur Nomor 281 Tahun 2016 (Tentang Organisasi dan Tata Kerja Peran Penanaman Modal DKI Jakarta dan Pelayanan Terpadu Satu Pintu), dalam rangka mewujudkan good governance telah dilakukan upaya peningkatan pelayanan publik dan investasi di DKI Jakarta. Sasaran strategis yang sangat penting. Oleh karena itu, DPM PTSP DKI Jakarta dapat merumuskan dan melaksanakan strategi, arahan, rencana atau kebijakan kegiatan untuk meningkatkan pelayanan publik dan investasi di DKI Jakarta. Berkaitan dengan hal tersebut, penerapan peraturan perundang-undangan terkait pelayanan publik dan investasi melalui one stop service policy untuk mengupayakan tercapainya pelayanan publik yang cepat, murah, mudah, transparan, pasti dan terjangkau, serta membantu mempermudah investor. Memperoleh informasi dan perizinan tentang investasi. DKI adalah ibu kota Provinsi Jakarta. Oleh karena itu, sukses tidaknya kinerja pelayanan dan capaian investasi tidak lepas dari peran DPM PTSP DKI Jakarta dalam merumuskan strategi dalam bentuk yang inovatif, menentukan arah kebijakan, dan melaksanakan rencana atau kegiatan yang direncanakan dan dianggarkan.

Sesuai dengan Rencana Strategis Biro Pelayanan dan Penanaman Modal Pelayanan Terpadu Satu Pintu Provinsi DKI Jakarta Tahun 2017-2022, visi implementasi kebijakan pelayanan satu pintu adalah "Solusi Izin Warga Negara Jakarta". Berikut penjelasan lebih lanjut mengenai visi DPM PTSP DKI Jakarta: 1). Menjadi solusi bagi investor untuk 


\section{Diana dan Aulina: "Analisis Inovasi Layanan Perizinan Pada Dinas Penanaman Modal dan Pelayanan Terpadu Satu Pintu (DPMPTSP) DKI Jakarta"}

berinvestasi di Jakarta dengan menciptakan lingkungan investasi yang mudah, cepat, nyaman, transparan dan langsung serta menjalankan bisnis 2). Sebagai solusi untuk mendapatkan pelayanan publik yang berkualitas, baik yang berlisensi maupun yang tidak 3). Sebagai solusi atas permasalahan perizinan dan non perizinan kualitas pelayanan publik yang mengedepankan nilai SETIA. "Motto Penanaman Modal Jakarta dan Pelayanan Terpadu Satu Pintu adalah "SETIA" yang artinya solusi, empati, ketegasan, inovasi dan andal sebuah solusi Metode atau metode yang digunakan untuk menyelesaikan masalah secara obyektif, dan layanan yang dapat memberikan solusi tanpa mendapat tekanan apa pun :

a.) Solusi

1) memberikan informasi terkait waktu yang dibutuhkan untuk menyelesaikan masalah

2) Tindak lanjuti dan pantau penyelesaian masalah

3) Menginformasikan hasil pemecahan masalah

4) Jika solusi tidak memenuhi ekspektasi masyarakat, dilakukan perbaikan layanan.

b) Empati keadaan pikiran yang membuat seseorang merasa atau menyadari bahwa mereka berada dalam perasaan atau keadaan pikiran yang sama dengan orang atau kelompok lain. Layanan empati meliputi:

1) Bagikan kesulitan dan perasaan orang lain

2) Kemampuan untuk mengontrol emosi

3) Peka terhadap bahasa sugestif

4) Berperan

c) Tegas Sikap berani dan percaya diri mengungkapkan benar dan salah dengan cara yang jelas, nyata dan tidak ambigu (tanpa ragu-ragu). Layanan tegas:

1) Membuat keputusan yang benar berdasarkan prosedur yang ada

2) Katakan yang sebenarnya dengan jujur

3) Kata-kata dan perbuatan

4) Penuh percaya diri dalam menyampaikan informasi

d) Inovasi

Proses inovasi dalam pengalaman faktual di tempat menjadi ide, ide, metode atau alat yang dapat memiliki nilai lebih. Layanan inovatif:

1) Fokus pada masa depan

2) Suka perubahan, dan terus berusaha meningkatkan (perbaikan)

3) Tidak hanya berbicara, tetapi untuk mewujudkannya dalam tindakan nyata, berani mengambil risiko yang terukur dan bertanggung jawab atas hasil 
Jejaring Administrasi Publik, Vol. 12, No. 1, 2020, hal 18-34

e) Andal

Dapat dipercaya, dan dapat memberikan hasil yang sama dari waktu ke waktu. Layanan yang andal:

1) Lakukan hal yang benar dengan integritas yang tinggi

2) Selalu kembangkan diri Anda untuk belajar dan berkembang

3) Mampu menjalin hubungan yang baik

4) Pertahankan sikap positif dan konsisten

Untuk mendeskripsikan visi tersebut maka tugas dari Dinas Penanaman Modal dan Pelayanan Terpadu Satu Pintu Jakarta adalah sebagai berikut:

1) Membimbing dan mengembangkan peralatan PTSP sesuai dengan kompetisi

2) Meningkatkan kualitas layanan berlisensi dan non-lisensi secara profesional

3) Memprioritaskan penggunaan sistem informasi untuk mempercepat pelayanan

4) Cepat menangani pengaduan masyarakat, dan

5) Menyediakan infrastruktur kerja yang memadai dan andal.

Dalam penyelenggaraan pelayanan berizin dan tidak berizin, jumlah SDM PNS yang dimiliki DPMPTSP masih belum dapat memenuhi kebutuhan SDM. Sebaiknya untuk mengatasi masalah kekurangan staf dengan memperbanyak penyedia layanan sesuai profesi yang dibutuhkan. Berdasarkan data dalam Laporan Akuntabilitas Kinerja Instansi Pemerintah (LAKIP) Dinas Penanaman Modal dan Pelayanan Terpadu Satu Pintu DKI Jakarta, terdapat 1.347 non PNS atau non PNS pada 2018. Penambahan penyedia layanan pribadi lainnya meliputi surveyor, surveyor pembantu, petugas shuttle bus perizinan manuver (AJIB), petugas informasi dan konsultasi (call center), petugas hubungan pelanggan, arsitek perizinan, inspektur gedung, kantor lokasi. Pejabat pengelola, pengurus komunitas, pekerja tidak tetap (PHL) dan Karaka. Semua SDM tersebut tersebar di seluruh titik layanan DPMPTSP di Jakarta. Di bawah ini adalah Daftar karyawan ASN dan non-ASN sebagai berikut :

Tabel 1

Daftar Pegawai ASN

\begin{tabular}{|l|c|}
\hline \multicolumn{1}{|c|}{ Penempatan } & Jumlah \\
\hline Dinas & 159 \\
\hline PSTIK & 17 \\
\hline Wilayah Pusat & 173 \\
\hline Wilayah Utara & 146 \\
\hline Wilayah Barat & 206 \\
\hline
\end{tabular}


Diana dan Aulina: "Analisis Inovasi Layanan Perizinan Pada Dinas Penanaman Modal dan Pelayanan Terpadu Satu Pintu (DPMPTSP) DKI Jakarta"

\begin{tabular}{|l|c|}
\hline Wilayah selatan & 265 \\
\hline Wilayah Timur & 292 \\
\hline Wilayah pulau Seribu & 24 \\
\hline Jumlah & 1282 \\
\hline
\end{tabular}

Sumber : DPMPTSP Jakarta 2020

Tabel 2

Daftar Pegawai Non ASN

\begin{tabular}{|l|c|}
\hline \multicolumn{1}{|c|}{ Profesi } & Jumlah \\
\hline Juru ukur danPenunjang Juru Ukur & 259 \\
\hline Pengolah data & 96 \\
\hline Petugas Antar Jemput Izin Bermotor (AJIB) & 200 \\
\hline Petugas Informasi dan Konsultasi (Call Center) & 28 \\
\hline Petugas Customer Relation Officer (CRO) & 300 \\
\hline Arsitek Perizinan & 16 \\
\hline Inspektur Bangunan & 16 \\
\hline Petugas Site Office Manager & 1 \\
\hline Petugas Community Manager & 1 \\
\hline Pekerja Harian Lepas (PHL) & 380 \\
\hline Caraka & 55 \\
\hline total & 1347 \\
\hline
\end{tabular}

Sumber : DPMPTSP Jakarta 2020

\section{Inovasi pelayanan perizinan DPMPTSP}

Sebelum "Orde Reformasi" dikeluarkan, DKI Jakarta terkenal dengan tingkat pelayanan publik yang rendah. Semua masalah bisa diselesaikan melalui pembayaran fasilitasi. Namun saat memasuki "Reformasi Order", DKI Jakarta mulai berbenah untuk mengedepankan kepuasan masyarakat, bahkan Jakarta telah banyak melakukan terobosan atau inovasi layanan, salah satunya adalah meningkatkan kualitas layanan berlisensi dan non lisensi yang cukup berpengaruh terhadap layanan. Kemudahan pengiriman. Kantor Pelayanan dan Investasi Terpadu Satu Pintu adalah sebagai berikut:

1). Atur mal layanan publik sebagai layanan satu atap

Pada tahun 2018, DPM PTSP telah menerbitkan 1.507.026 izin, dan rata-rata jumlah layanan yang diberikan per hari kerja adalah 5.708. Terdapat 328 izin di tingkat provinsi, 


\section{Jejaring Administrasi Publik, Vol. 12, No. 1, 2020, hal 18-34}

kabupaten, kota, jalan, dan kabupaten, sedangkan PTSP di tingkat pusat dan daerah. Kerja sama antar pemerintah.

2). Layanan satu hari (ODS)

Memberikan layanan cepat, proses layanan selesai dalam 1 hari.

3). Antar Jemput Izin Listrik (AJIB)

Munculnya Penanaman Modal dan Pelayanan Terpadu Satu Pintu (DPMPTSP) DKI Jakarta Pelayanan Door to door (AJIB) merupakan terobosan inovasi yang bertujuan untuk meningkatkan kualitas pelayanan dan memudahkan masyarakat dalam menghemat waktu dan biaya dalam proses perizinan. Dan hilangkan praktik. Perantara / broker berlisensi.

4). Sederhanakan izin usaha dan perdagangan

Penyederhanaan proses pelayanan perizinan komersial, yang sebelumnya 165 selesai dalam 165 hari kerja menjadi 43 hari kerja.

5). Layanan arsitek gratis

Sesuai peraturan permukiman, luas tanah maksimal 200 meter persegi, dan masih kosong.

6). IMB 3.0

Ini adalah layanan manajemen nama tempat tinggal yang digunakan untuk mengelola IMB dan dapat diselesaikan dalam waktu 3 jam dari syarat dan ketentuan yang berlaku.

7). Unit Layanan Seluler (MSU),

a) Izin dapat diproses dalam satu hari;

b) Jenis izin yang diproses di MSU meliputi: izin penggunaan pemakaman (IPTM), legalisasi izin, dan izin penelitian. Lokasi MSU: kawasan industri, pelabuhan, kawasan perkantoran dan pemakaman umum (TPU). Memberikan layanan informasi dan konsultasi perizinan melalui telepon atau video call. Pusat panggilan PTSP 1500164

8). PTSP online

Melalui pendirian bengkel di seluruh kawasan Mall Jakarta, melalui pelayanan kepada masyarakat dan cara-cara yang nyaman, sinergi antara pemerintah dan pelaku usaha dapat mewujudkan pelayanan publik yang luar biasa di Jakarta. PTSP mendatangi pusat perbelanjaan ini diadakan dengan tujuan untuk mendekatkan layanan berlisensi dan tidak berlisensi kepada masyarakat. Saat warga yang berkunjung ke mal bisa bertanya perihal perizinan yang harus mereka urus.

9.) Jika tidak ada persyaratan perantara, RPTKA dan izin API dapat diproses dengan cepat dalam waktu 1 hingga 3 hari kerja. 


\section{Diana dan Aulina: "Analisis Inovasi Layanan Perizinan Pada Dinas Penanaman Modal dan Pelayanan Terpadu Satu Pintu (DPMPTSP) DKI Jakarta"}

10). Legalitas tanda tangan elektronik untuk penerbitan izin dan nonperizinan melalui sistem teknologi informasi. Terobosan inovatif ini adalah penerbitan izin melalui pendaftaran online. Warga dapat mendaftar untuk mendapatkan lisensi secara online, dan sesuai dengan persyaratan pengunggahan daftar, mereka dapat mencetak tanda tangan elektronik dengan kode batang setelah memproses izin usaha. Hal ini untuk menghindari pihak-pihak yang tidak bertanggung jawab membuat lisensi palsu / tidak terdaftar.

11). Antrian online

Memberikan layanan tertentu bagi pelamar berlisensi dan non-lisensi untuk memastikan bahwa mereka dapat mengantri sesuai dengan waktu yang dijadwalkan.Anda bisa mendapatkan nomor antrian dengan membuka http://ptsp.jakarta.go.id, yang diperuntukkan bagi warga untuk memproses izin Tidak akan mengantri untuk waktu yang lama.

12) Jakarta Investment Center (JIC)

Layanan khusus ini merupakan layanan khusus yang diluncurkan pada peringatan HUT DKI Jakarta yang bertujuan untuk mengembangkan potensi ekonomi dan investasi daerah dengan memberikan kemudahan bagi investor, mempermudah pertukaran perdagangan dan meningkatkan investasi di Jakarta.

13).Layanan perizinan online, URL-nya http://pelayanan.jakarta.go.id dan http://jakevo.jakarta.go.id. Mengembangkan JAK EVO, aplikasi untuk pemrosesan izin online di DKI Jakarta.

\section{Dampak inovasi layanan perizinan}

Melalui aplikasi dan website http://pelayanan.jakarta.go.id dan http://jakevo.jakarta.go.id, inovasi dilakukan secara online untuk meningkatkan dampak dari layanan berlisensi dan non lisensi. Dan melalui manual yang disediakan oleh kantor PTSP, yaitu memastikan masyarakat memperoleh jaminan layanan sesuai SOP yaitu jaminan prosedur, kondisi, waktu dan biaya, serta diharapkan dapat mengurangi jumlah calo yang merugikan pemohon.

Berikut adalah hasil wawancara dengan Kepala Dinas Penanaman Modal dan Pelayanan Terpadu Satu Pintu (PMPTSP) di Jalan Pasar Rebo. Masyarakat semakin perlu mendapatkan kejelasan dan kepastian secara tepat waktu untuk mengurus izin dan non izin, sehingga perlu dilaksanakan inovasi yang dikembangkan oleh DPM PTSP DKI Jakarta beserta karyawannya. Demikian pula, departemen manajemen PMPTSP di distrik Pasal Rebo bertanggung jawab untuk mendukung dan mengembangkan inovasi layanan, seperti yang 
dikatakan oleh Bapak Netra Dewangga (kepala departemen pelaksana PMPTSP di distrik Pasal Rebo): "Kami senantiasa mendukung segala inovasi yang dilakukan DPM PTSP untuk meningkatkan pelayanan publik. Kami mendukung rencana inovatif yang dibuat oleh UP PMPTSP Pasar Rebo ini, yaitu untuk mempercepat penyelesaian Undang-Undang Perencanaan Kota (KRK), yang KRK harus dimiliki sebelum diterbitkannya IMB.

Secara strategis, petugas tersebut disuruh memetakan segera setelah memberikan fasilitas dan pengawasan. Kegiatan inovatif ini sudah kami laksanakan, seperti PTSP pergi ke pusat perbelanjaan, setelah kami jemput bola dan mendapat pujian dari masyarakat, kami akan menjalankannya setiap bulan dan mengatur jadwal. (Sumber: Wawancara Pak Netra pada WIB Senin, 17 November 2020). Masyarakat harus dibuat mudah diakses oleh layanan berlisensi dan tidak berlisensi dan informasi terkait dengan layanan berlisensi dan tidak berlisensi, terutama untuk memahami persyaratan dan prosedur serta cara menyelesaikan pengaturan lisensi. Teknologi informasi kembali memberikan kemudahan akses bagi masyarakat untuk memahami kegiatan sosial pemerintah dalam memberikan pelayanan dan pengaduan. DPM PTSP menggunakan teknologi informasi untuk proses perizinannya, yang dapat dilakukan secara online atau melalui aplikasi yang dapat diakses publik. Ini dengan anggota staf PNS UP PMPTSP Kecamatan Pasar Rebo "Rata-rata pendaftarannya online, hanya sedikit yang masih manual, dan izin masuknya lebih banyak dari pada manual online. Melalui layanan jakarta.go.id kami menyediakannya dengan JakEvo. (Sumber: 17 November Minggu, Senin, wawancara Bank Dunia dengan Tuan Vega pada pukul 11:00). Dampak dari inovasi layanan permisif dan non permisif yang dilakukan secara online melalui akun http://jakevo.jakarta.go.id, berikut adalah hasil wawancara dengan Bapak Sukron: Sekarang saya mendapatkan izin dengan sangat cepat, kali ini saya mengajukan izin SPPL untuk praktik bidan pribadi. Jujur saya dari Gabtek, tapi AJIB mas ANTON bilang orang ini sangat baik. Saya dipandu dari membuat akun hingga mengunggah file. Kemudian jika dalam 1 hari ijin SPPL saya selesai dan diantarkan ke rumah yang semuanya gratis. Menurut saya AJIB sangat bermanfaat, apalagi untuk orang lanjut usia seperti saya, saat ini saya sedang berkonsultasi dengan persyaratan praktik bidan pribadi (Sumber: Wawancara dengan Pak Sukron, WIB, Senin, 18 November).

Namun berdasarkan hasil penarikan infromasi dengan warga, DPMPTSP DKI Jakarta memberikan beberapa saran untuk dilaksanakannya adopsi layanan AJIB tingkat rendah oleh masyarakat. Selain regulasi yang mendukung pelaksanaan layanan AJIB, perlu juga meningkatkan sosialisasi layanan AJIB kepada masyarakat, dan Meningkatkan akses ke 


\section{Diana dan Aulina: "Analisis Inovasi Layanan Perizinan Pada Dinas Penanaman Modal dan Pelayanan Terpadu Satu Pintu (DPMPTSP) DKI Jakarta"}

layanan AJIB. Server http://jakevo.jakarta.go.id perlu diperbaiki agar tidak sering down. Akibatnya pelayanan ke masyarakat tidak terganggu dan dapat berjalan dengan baik..

\section{Beberapa Prestasi DPMPTSP DKI Jakarta}

1) Museum Rekor Dunia Indonesia (Muri) menganugerahkan penghargaan kepada Badan Penyelenggara Pelayanan Terpadu Satu Pintu (BPTSP) DKI. Penghargaan tersebut diberikan karena BPTSP DKI telah merilis 4.138.021 layanan berlisensi dan non lisensi selama tahun 2015. Rekor ini terus dipecahkan oleh DPMPTSP DKI Jakarta yang tercatat di 4.327.404 tahun 2016 dan 5.330.060 tahun 2017.

2) Berdasarkan laporan Bank Dunia (EoDB) tahun 2018, Indonesia berada di peringkat 72. Dalam dua tahun terakhir, naik 34 peringkat.

3) Tempat-tempat di mana Jakarta memainkan peran penting dalam survei EODB (yaitu kota-kota yang mewakili Indonesia) akan dihitung dengan bobot $78 \%$.

4) Ombudsman Republik Indonesia (ORI) memberikan predikat kepatuhan tinggi (zona hijau) kepada Pemerintah Provinsi DKI Jakarta dengan skor 85,43. Nilai ini didapat setelah tim survei mengambil sampel 1.790 produk jasa, yang secara merata mendistribusikan proses jasa manajemen berizin dan tidak berizin dari tingkat atas hingga kelurahan.

5) Laporan hasil Indeks Persepsi Inovasi Pelayanan Publik Tahun 2017 yang dirilis oleh Pusat Inovasi Pelayanan Publik Sekolah Nasional Administrasi Jakarta dan Wakil Direktur Lembaga Inovasi Administrasi Nasional memperoleh skor indeks persepsi inovasi pelayanan publik sebesar 82,90, dan tingkat kualifikasi inovasi pelayanan publik adalah A (Sangat inovatif).

6) Tertinggi di Indonesia, investasi DKI Jakarta mencapai 108,6 triliun rupiah.Menurut data Badan Koordinasi Penanaman Modal (BKPM), baru kali ini capaian investasi DKI Jakarta menduduki peringkat pertama di Indonesia.

7) Memenangkan penghargaan panutan penyelenggara pelayanan publik kategori "Sangat Baik" yang diberikan oleh Kementerian Pendayagunaan Aparatur Negara dan Reformasi Birokrasi (KemenPANRB). Penghargaan ini merupakan yang pertama kali diraih DPMPTSP DKI Jakarta

8) Memenangkan penghargaan "Pelayanan Publik Tahunan Jabodetabek 2018" dari Markplus, Inc. Sebagai perusahaan konsultan terkemuka di Indonesia dan Asia Tenggara, ini pertama kalinya DPMPTSP DKI Jakarta meraih Jabodetabek Annual Public Service Award 2018 
9) Pemprov pertama. DKI Jakarta melalui DPMPTSP Jakarta DKI memenangkan Penghargaan Penanaman Modal 2018 dari Badan Koordinasi Penanaman Modal Republik Indonesia (BKPM) dan menjadi penyelenggara pelayanan satu pintu provinsi (PTSP) terbesar ketiga tahun 2018.

10) Meraih penghargaan 99 lomba inovasi pelayanan publik yang diserahkan langsung ke Pemprov DKI Jakarta oleh Menteri Pendayagunaan Aparatur Negara dan Reformasi Birokrasi (PAN-RB) melalui DPMPTSP Provinsi DKI Jakarta tahun 2018 bertajuk " Inovasi PTSP Masuk Pusat Perbelanjaan " Sinergi antara pemerintah, swasta dan masyarakat ". Evaluasi masih menuju TOP 40 yang diumumkan pada November lalu. Penghargaan tersebut pertama kali diraih oleh DPMPTSP DKI Jakarta di bawah kepemimpinan Gubernur Anies.

11) Pemprov DKI Jakarta meraih penghargaan " Indonesia Attraction Award (IAA) 2018 Best Investment Place " kategori silver award yang diselenggarakan bersama oleh PT Tempo Inti Media Tbk (Tempo Media Group) dan Frontier Consulting Group

12) Berdasarkan jumlah beban dan PAD lainnya, total pendapatan tahun 2017 adalah 989,85 miliar rupiah, dan persentase realisasi pendapatan $129,70 \%$, meningkat $28 \%$ dibandingkan periode yang sama tahun lalu. 773,3 miliar, terhitung 100,5\% dari pendapatan yang direalisasikan.

13) Penyederhanaan perizinan dan nonperizinan.Dengan berlakunya Peraturan Gubernur Nomor 47 tentang Pedoman Pelaksanaan Pelayanan Terpadu Satu Pintu tahun 2017, perizinan dipermudah pada April 2017. Sebelum 2015, terdapat 518 izin / nonperizinan. Ada 465 lisensi / non lisensi per tahun, dan saat ini ada 269 lisensi / non lisensi. Sesuai dengan prinsip menyederhanakan layanan berlisensi dan nonlisensi, Salah satunya adalah menghindari duplikasi pelayanan dan efisiensi.

14) Perizinan Elektronik, Peraturan Gubernur Nomor 205 Tahun 2015 tentang Penyelenggaraan Pelayanan Perizinan dan Non Perizinan Elektronik DPM PTSP DKI Jakarata telah mengalihkan perizinan secara online, dan masyarakat dapat memilih hingga 238 perizinan / non perizinan dari total 269 perizinan / non perizinan Dapatkan izin masuk.

\section{Kesimpulan}

Tata kelola yang baik berarti pemerintahan yang efektif, efisien, transparan, akuntabel dan bertanggung jawab. Dalam rangka peningkatan tata kelola pemerintahan yang baik, Dinas Penanaman Modal dan Perizinan dan Nonperizinan telah melakukan sejumlah 


\section{Diana dan Aulina: "Analisis Inovasi Layanan Perizinan Pada Dinas Penanaman Modal dan Pelayanan Terpadu Satu Pintu (DPMPTSP) DKI Jakarta"}

inovasi yang bertujuan untuk memberikan pelayanan perizinan yang sederhana dan transparan kepada masyarakat melalui terobosan / inovasi baru seperti berikut: One-day service (ODS), memberikan pelayanan cepat, dan proses pelayanan selesai dalam 1 hari., Electric License Shuttle (AJIB) yang menyediakan layanan shuttle untuk semua dokumen perizinan hingga pengurusannya selesai. Mempermudah perizinan niaga dan perdagangan serta mempermudah proses pelayanan perizinan niaga. Sebelumnya 165 diselesaikan dalam waktu 165 hari kerja menjadi 43 hari kerja. Siup dan TDP Online: Saat ini pemrosesan izin usaha dapat dilakukan selama 6 jam sekaligus, yaitu siup dan TDP. Jasa arsitek gratis, asalkan luas tanah maksimal rumah 200 meter persegi dan masih terbuka. IMB 3.0 adalah layanan yang digunakan untuk mengelola merek tempat tinggal lainnya dan dapat diselesaikan dalam waktu 3 jam dari syarat dan ketentuan yang berlaku. Mobile Service Unit (Auto Ajib) yang secara langsung mengumpulkan dokumen perizinan di tempat umum. Call center PTSP 1500164 menyediakan layanan informasi dan konsultasi perizinan melalui telepon atau video call. Terdapat sebanyak 316 unit pelaksana PTSP yang tersebar di kota / wilayah DKI, wilayah, kelurahan dan mal layanan umum di Jakarta. Sinergi antara pemerintah dan perusahaan peserta adalah mewujudkan pelayanan publik yang prima di Jakarta dengan membuka bengkel di kawasan pusat perbelanjaan seluruh Jakarta, serta dengan memberikan pelayanan dan kemudahan kepada masyarakat. Jika diperlukan tanpa perantara, laporan izin kehadiran tenaga kerja asing (LKTKA) akan diproses dengan cepat dalam waktu 1-3 hari kerja. Tanda tangan elektronik, legalitas izin dan non izin diterbitkan melalui sistem teknologi informasi. Antrian Online, untuk mengetahui kepastian pelamar berlisensi dan tidak berlisensi untuk memberikan layanan pada waktu yang dijadwalkan. Jakarta Investment Center (JIC), layanan khusus yang dirancang untuk mengembangkan potensi ekonomi dan investasi daerah dengan memfasilitasi investor, mempermudah kontak bisnis, dan meningkatkan investasi di Jakarta melalui satu pintu.

Dari semua layanan tersebut tentunya harus dapat dimanfaatkan sebaik-baiknya bagi kepentingan warga Jakarta Khusunya, sehingga masyarakat tidak perlu repot-repot mengantri ditempat-tempat pelayanan, dan hal ini sangat membantu bagi warga mengingat Ibukota Jakarta adalah memiliki mayarakat yang komplek, sibuk serta beragam kebutuhan yang tentunya sudah harus dengan cepat dapat terlayani serta agar tidak terjadi penumpukan pekerjaan terutama bagi petugas terkait. Dengan adanya inovasi tersebut dimungkinkan dapat memberikan terobosan yang baik terhadap pelayanan khususnya DPMPTSP dan bisa menjadi contoh pada layanan lainnya, baik di Jakarta, dan umumnya di Indonesia. Karena 


\section{Jejaring Administrasi Publik, Vol. 12, No. 1, 2020, hal 18-34}

jika hal ini dimanfaatkan dengan baik oleh masyarakat, akan berdampak positif bagi kepentingan pemerintah mapun masyarakat itu sendiri.

\section{Daftar Pustaka}

Akbar, M. F., \& Mohi W. K. (2018). Studi Evaluasi Kebijakan: Evaluasi Beberapa Kebijakan di Indonesia (Pertama). Gorontalo: Ideas Publishing

Anonim. (2007). Mengukur Kinerja Pelayanan Terpadu untuk Perizinan Usaha di Indonesia. The Asia Foundation.

Dinas PM dan PTSP Provinsi DKI Jakarta.INOVASI LAYANAN AJIB.http://pelayanan.jakarta.go.id/\#tentang-ptsp

Jakevo. Provinsi DKI Jakarta. https://jakevo.jakarta.go.id/

Jones, C. P. (1943). Investment: Analisis and Management (Keduabelas). United States of America: Library of Congress Cataloging-in-Publication Data.

Kubicek, H. \& Hagen, M.. (2001). One-Stop Government in Europe: An Overviezv, https://www.researchgate.net/publication/253447324.

Lemius, V. (1986). Tentang Otonomi Daerah. Jakarta: Binarupa Aksara

Ratminto \& Winarsih, Atik S (2006). Manajemen Pelayanan: Pengembangan Model Konseptual, Penerapan Citizen's Charter dan Standar Pelayanan Minimal, Yogyakarta: Pustaka Pelajar.

Sarwono J. (2006). Penelitan Kualitatif dan Kuantitatif. Yogyakarta: Graha Ilmu.

Sinambela (2008) Reformasi Pelayanan Publik: Teori, Kebijakan, dan Implementasi, Jakarta Bumi Aksara

Sukirno, S. (2008). Mikro Ekonomi Teori Pengantar. (Jakarta, Ed.). P.T Raja GrafindoPersada.

Suwarno, Yogi. (2008). Inovasi di Sektor Publik. Jakarta. STIA-LANPress

Trochidis,I..(2008). One-Stop Government: A Literature Review, www.onestopgovproject.org, http://www.fub.it/files/onestop gov literature review.pdf,

Laporan Triwulan IV PMPTSP Kecamatan Pasar Rebo tahun 2019 tentang Inovasi DPMPTSP

Peraturan Gubernur Nomor 281 Tahun 2016 Tentang Organisasi dan Tata Kerja Peran Penanaman Modal DKI Jakarta dan Pelayanan Terpadu Satu Pintu. 
Diana dan Aulina: "Analisis Inovasi Layanan Perizinan Pada Dinas Penanaman

Modal dan Pelayanan Terpadu Satu Pintu (DPMPTSP) DKI Jakarta"

Peraturan Gubernur Nomor7 Tahun 2016 Tentang Perubahan atas Peraturan Gubernur Nomor 57 Tahun 2014 tentang Pelaksanaan peraturan Daerah Nomor 12 Tahun 2013 Tentang Penyelenggaraan Pelayanan Terpadu Satu Pintu

Permadi,R.N.2018. Mewujudkan 'Good Governance' Melalui

Inovasi.https://news.detik.com/kolom/d-4012818/mewujudkan-good-governancemelalui-inovasi. 